\title{
Challenges of Public Management to Consolidate the Gulf of Morrosquillo as a Competitive Tourism Destination
}

\author{
Hassir Lastre Sierra, Placido R. Cruz Chávez \\ Universidad Autónoma de Baja California Sur, Mexico
}

\begin{abstract}
The theoretical discourse focuses on unscrambling the differences between public management and private management, while new tools and techniques have been provided by recent trends in public management. This paper centers on a critical analysis and what the purpose of the government's management is; which refers to consolidate the Gulf of Morrosquillo (Colombia) as a competitive tourism destination for it to be as relevant as any other tourism destinations. Even though public management never stops, it is imperative for the governance to delineate the appropriate development path of a region to guarantee the correct conditions for it to be promoted properly. Methodologically speaking, this paper was started with the revision of the literature about the macro-environment related to touristic activities and an instrument was used to collect the information, which was designed to gather data about the lodging establishments. It is necessary to raise the awareness of the public management of the different municipalities that form the Gulf of Morrosquillo for them to acknowledge their weaknesses so that they will be able to formulate the appropriate programs to improve the estate of the destination.
\end{abstract}

Keywords: public management, competitiveness, development, and tourism destination

\section{Introduction}

Public management has become a fundamental motivation to prone in the direction of progress and to upsurge tourism. Recently, it has been obvious that public management has moved toward the expansion of strategies to promote tourism growth and its inclusion in different levels of development but, even though public management has put a lot of effort into this, it is noticeable that it is not as efficient because of the changes made in its instruments and the methods of intervention.

The Gulf of Morrosquillo is located in Colombia and its $17 \mathrm{~km}^{2}$ are shared by the Provinces of Córdoba and Sucre. Along this geographical area, we can find the coastal cities "Santiago de Tolú" and "Coveñas", which are part of the province of Sucre and "San Antero" which is part of the province of Córdoba. This investigation took place in three of the five municipalities that are part of the region; "Santiago de Tolú", "Coveñas", and "San Onofre”. The three municipalities cover most of the littoral of the sub region Gulf of Morrosquillo and they are part of the Province of Sucre. This zone has a broad natural wealth, which has encouraged tourism to be more significant economic activity impulsing the service industry of the region. For years, it has been believed that the major economic activities held by the Province of Sucre are agriculture and commerce; however the tertiary sector provides 33.6\% of the GDP of Sucre; whereas agriculture provides $12.1 \%$ and commerce $8.2 \%$ (MinCIT, 2016).

Hassir Lastre Sierra, Master’s student, Department of Economics, Universidad Autónoma de Baja California Sur. Email: hlastre04@gmail.com.

Placido R. Cruz Chávez, Professor, Department of Economics, Universidad Autónoma de Baja California Sur. 
Taking into consideration the importance of tourism in the province of Sucre, this paper has as an objective to give an analytical and critical view about the public management, and its impact on consolidating the Gulf of Morrosquillo as a competitive tourism destination, for it to be as relevant as any other national tourism destinations, e.g., "Cartagena de Indias". The intention of this research is to be part of the literature related to the topic and for it to be used as an informative instrument to support the planning and management of the touristic features of the region.

This paper is the result of a research related to the accommodation establishments located in the Gulf of Morrosquillo and it is structured in four sections. The next segment exposes the theoretical collection on which the study of public management was founded; the third segment describes the methodology proposed and implemented to comply with the research objectives. In the study, it was considered relevant to analyze the macro-environment of tourism activities, with the purpose of getting to know more about the problem and to identify the actions of local governments for the development and promotion of tourism. The information obtained was contrasted with the theory with the objective of recognizing and reflecting the challenges that the public managers of this region must face that is the reason why the fourth section is dedicated to that. The final section is devoted to the conclusions that the authors make as a result of their investigative work.

\section{Literature Review}

To understand public management, it is necessary to recognize that it responds to a social and economic model that will be promoted by the governing authority. Public management has as an objective to study the variables and the inconvenience of the designation and operation of public services. That is the reason why when talking about public management, there are at least two factors that have to be taken into consideration: public administration and public policies (Hood, 2000; Lynn, 1996).

According to Losada (1999), public management seeks to decrease the economic pressure caused by the scarcity of monetary resources and the necessity to assist those who demand public services. That is the reason why public management discloses the manner an estate handles its organisms and how the authorities formulate and execute their public policies. The process of management is a collective and participative action which integrates different factors for the government to lessen two fundamental problems of the collective action: cooperation and its effectiveness (Ochoa \& Fuenmayor, 2006; Aguilar, 2007).

Public management is experiencing two variants in its progress. The first one is related to the new tendencies of the governments to diminish their intervention in national economies; and the second one refers to the increasing of the effectiveness and the responsibility that emanates from the necessities of a society (Ávalos Aguilar, 2015). The combination amongst the "new institutionalism” and the professional management has resulted in the emergence of a new philosophical trend in public management which breaks with the milestone of the differences amid public and private management. Through the new institutionalism, it is presumed that the public entities have the capacity to understand the interactions among the subjects; for the mechanisms they apply permit to condition the preferences of each individual (Hood, 1991; Arellano, 2002; Lapsley \& Oldfield, 2001). 


\section{Methodology}

The analysis made in this paper commenced from the revision of the literature about the macro-environment related to touristic activities. This research deepens in the study of the economic, social, legal, cultural, and technological variables with the objective of knowing and diagnosing the general situation in the Gulf of Morrosquillo. After that, an instrument to collect the information was designed to gather data about the lodging establishments. The instrument was constituted by eight categories, such as business activity, property structure, size indicators, managerial profile, human resources, facilities capacity, quality, and managerial cooperation. Each category was integrated by different criteria. In the end, there were 28 questions. The operationalization of the variables used in this methodology is presented in Table 1.

Table 1

Operationalization of Variables

\begin{tabular}{|c|c|c|}
\hline Variable & Category & Indicators \\
\hline \multirow{8}{*}{ Designation } & Managerial activity & Name of the establishment, category of the establishment, municipality, and their market target. \\
\hline & Property structure & Family company, type of company, number of associates, board of directors. \\
\hline & Size indicators & Number of employees, social activities. \\
\hline & Managerial profile & Gender, age, level of education, usage of a second language. \\
\hline & Human resources & $\begin{array}{l}\text { Full-time employees, part-time employees, employees with a contract, temporary employees, } \\
\text { gender of the employees, age of the employees, level of studies of the employees. }\end{array}$ \\
\hline & Facilities capacity & Number of rooms, number of beds, type of rooms, occupation percentage. \\
\hline & Quality & Quality certifications, quality evaluations. \\
\hline & $\begin{array}{l}\text { Managerial } \\
\text { cooperation }\end{array}$ & Agreements with any other company, being part of any association. \\
\hline
\end{tabular}

Note. Source: Elaborated by the authors.

As it was mentioned before, this study took place in the sub region of the Gulf of Morrosquillo in the Province of Sucre in Colombia. Even though the sub region is formed by five municipalities - Coveñas, San Antonio de Palmito, Santiago de Tolú, Toluviejo and San Onofre - for this research only three of them were selected - Santiago de Tolú, Coveñas and San Onofre, taking into consideration that these three municipalities are adjacent to the coastal line of the gulf. The study universe was formed by 98 lodging establishments which had an active mercantile registration in 2015 (Commerce Chamber of Sincelejo, 2015).

The calculation of the representative sample obeyed the guidelines of the technique of simple random sampling, where the values of the proportions $\mathrm{p}$ - q were determined from a previous pilot study. In addition, a certainty level of $95 \%$ and an error level of $+/-7.5 \%$ were taken into account. Accordingly, the representative sample was determined to be 31 elements. However, it was necessary to distribute the sample proportionally amongst the three municipalities and then amid the different types of establishments: hotel, cottage, aparthotel (see Table 2).

Table 2

Distribution of the Random Sampling

\begin{tabular}{llllr}
\hline \multirow{2}{*}{ Object of study } & \multicolumn{3}{c}{ Elements } & Total \\
\cline { 2 - 5 } & Hotels & Cottages & Aparthotels & 18 \\
Coveñas & 7 & 7 & 4 & 12 \\
Santiago de Tolú & 9 & 2 & 1 & 1 \\
San Onofre & 1 & - & - & 31 \\
\hline
\end{tabular}

Note. Source: Elaborated by the authors. 
As it is exposed in Table 2, in the municipality of Coveñas, 7 hotels, 7 cottages, and 4 aparthotels were part of the study. In Santiago de Tolú, 9 hotels, 2 cottages and 1 aparthotel were part of the study. In San Onofre, just one hotel was part of the study.

\section{Discussion Results}

\section{Tourism Context of the Gulf of Morrosquillo}

Even though tourism as an economic activity generates revenues and favors the progress and the development of the municipalities that constitute the Gulf of Morrosquillo, it has not been deeply studied the impact that is created by this economic activity. The figure and data related to the amount of visitors, and real benefits generated by tourism are unknown. Touristic activities lack proper institutional regulation reflected in the dearth of public policies to promote sustainable tourism development. Although $80 \%$ of the tourists that visit the municipality of Santiago de Tolú are only interested in being sun and water tourism, public management has overlooked the precarious state of the municipality's infrastructure, which is not limited to the road network, but comprises public services, connectivity and touristic plant (Municipal Development Plan of Santiago de Tolú 2012-2015).

From all the municipalities that are part of the Gulf of Morrosquillo, Coveñas is the one that is visited the most, because of its natural wealth, its indigenous reserves, and its cultural heritage. It also has a warm, calm, and shallow sea and places like "La Caimanera Swamp" or "Villeros Dam" which give it the advantage amongst the rest of the municipalities. Coveñas has all the elements to become one of the most competitive tourism destinations. However, the destination is not competitive (Development Plan of Coveñas 2012-2015). The inadequate planning, its dependence in peak seasons, the excessive informality and not using the new technologies properly have triggered that the touristic potential of the region has not been exploited adequately. Coveñas depends mainly on the tertiary sector which has caused that any progress related to the primary sector has been put aside.

The municipalities that are part of the region of the Gulf of Morrosquillo face a significant lack of human resources formation which results in a low quality of the services. On the other side, the promotion of this zone as a tourism destination is deficient due to the absence of adequately designed tourism products. Talking about tourism security, the support of the different entities correlated to security is inexistent in the entire area. As an example, Coveñas does not have a Tourism Police Department; in addition, there are insufficient brigades and lifeguard towers (Development Plan of Coveñas 2012-2015, 2012).

Because of the climate conditions, the road network is not in good conditions in spite of the maintenance work that has been done. Along the $14.1 \mathrm{~km}$ of "La Troncal del Caribe roadway", which is part of the municipality of Coveñas, severe deterioration and inappropriate signalization is evident. As a result, it is necessary to repair it for it to be durable and to guarantee the safety of the visitants. On the other side, taking into account that efficient public transportation is nonexistent, the usage of "bicitaxis" and "mototaxis" has massified with no regulation at all. None of the municipalities has a station, so each transportation company has a large area for the reception and dispatch of passengers which generates traffic especially in the peak season.

The municipality of Santiago de Tolú has different wharfs; one of them is operated by "Sociedad Portuaria Golfo de Morrosquillo S.A.”, where the production of the cement plants settled in the area is exported. In another area of that municipality, there is the dock of the company "Pestolú" which has the appropriate infrastructure according to its operational capacity. There is also a tourist pier that, in spite of not having the 
proper conditions, is used to sell food and as a berth for small boats. Tourism companies that provide nautical services have designed piers with the purpose of improving the transportation of tourists to the islands of "San Bernardo” (Municipal Development Plan of Santiago de Tolú 2012-2015). In this municipality, it is the Gulf of Morrosquillo Airport that has a daily flight operated by the company Antioquia Airlines which covers the route "Tura Medellín” to "Santiago de Tolú" in addition to some charter flights from different airlines of the region.

Another aspect related to tourist activities in the different municipalities of the Gulf of Morrosquillo is the use of public spaces. This usage causes a series of problems, such as the reduction of pedestrian walkways. This situation is aggravated by the absence of policies and plans that delimit the use of public spaces.

Colombian Law 300 of 1996 in its Article 61 establishes the creation of the National Registry of Tourism (NRT). This law legitimizes and regulates tourism activities. All tourism providers in the country are obliged to register in it and to update the information annually (MinCIT, 2013). According to the NRT, in the Province of Sucre, there are 545 listed tourism providers; $87.5 \%$ of which are lodging establishments; $10.1 \%$ are travel agencies; $1.3 \%$ are gastronomy establishments; $0.4 \%$ are tour guides and land transportation companies; and $0.2 \%$ are tourism vehicle lessors and professional operators of congresses, fairs and conferences (Network of Commerce Chambers, n.d.). However, when detailing the NRT database, it was found that only about $54 \%$ of the registered providers have their registry active. The remaining $56 \%$ of the establishments have their registration pending to be updated, suspended, or canceled, which means that they provide their services irregularly or that they are providers that are not working in its social object.

According to the Commerce Chamber of Sincelejo, in 2015 in the municipalities of Santiago de Tolú, Coveñas and San Onofre, there were 246 lodging establishments - 53.3\% hotels, 42.6\% cottages, and 3.6\% aparthotels - about $40 \%$ of them had their mercantile registration active. Even if the tourism development of the region is founded on a large number of tourism providers, an enormous part of them carry on their activities informally and illegitimately (Province Development Plan of Sucre 2012-2015). This is a province which according to the Gross Domestic Product (GDP), the revenues of the tertiary sector represent $33.8 \%$ of the total GDP - ratifies its vocation to this sector. Even so, tourism providers dedicated to accommodation do not provide their services within the parameters of quality and legality. Nonetheless, lodging establishments alongside restaurants contribute $7.1 \%$ to the GDP of the Province; which is way above the national average of 3.5\% (MinCIT, 2016).

\section{The Role of Public Management in the Competitive Development of the Gulf of Morrosquillo}

Policies, as a legitimate mechanism of public management, demonstrate that governors have the commitment to take advantage of the resources and to safeguard them with the purpose of boosting the competitiveness of the region (Lastre Sierra \& Cruz Chávez, 2016a). However, the Province of Sucre shows lack of interest and lack of knowledge about the tourism sector since adequate policies are not designed to stimulate and promote the competitiveness of this activity (Province Development Plan of Sucre 2012-2015).

The consolidation of the Gulf of Morrosquillo as a competitive tourism destination requires that the inadequacies of government agencies are remedied, as the entities in charge of the promotion and coordination of tourism activities have demonstrated their inoperability by hindering the process of implementation of the policies that lead the tourism in the Province (Strategic Plan for Tourism Development in Sucre 2011-2012). Public management and tourist management in Sucre have not created the necessary conditions for this sector to achieve a great competitive development. 
Managers in the region should be concerned about integral public management, taking into consideration all aspects related to adopting a competitive and sustainable tourism development. The task of public management should not be reduced to the acceptance of the tourism potential of the Gulf of Morrosquillo. It is necessary to take advantage of the competitive advantages of the area in order to foster the flow of capital-investment that contributes to the consolidation of the tourism destination. The public management of the municipalities that are part of the Gulf should be directed towards the implementation of policies and strategies that favor the provision of domestic services, which promote the improvement and expansion of the road network, and that train high-level human talent. Taking into account what has been said, some of the necessary conditions have been generated to release the economic growth of tourism activities. In addition, the benefit is extended to other sectors, such as the social sector, taking into consideration that tourism enjoys a certain transversely interconnection with other sectors.

It may not be the solution to all the weaknesses that the Gulf of Morrosquillo must face in order to consolidate itself as a competitive tourism destination at a national and an international level, but the tourism clusters represent a strategic, competitive and sustainable launch, which is able to promote the necessary conditions pro economic growth and improvement in the region. Clusters in tourism sector promote cooperation and competence. These emanate from the integration of tourism providers who share the same activity (Lastre Sierra \& Cruz Chávez, 2016b).

According to what has been said, it is the chore of public managers to envision, as one of the possibilities, the development and consolidation of the Gulf through cooperation amid the most preponderant tourism providers in the Gulf which are the accommodation establishments. On the other hand, according to the results of the study, about $84 \%$ of the accommodation establishments in the Gulf of Morrosquillo have no alliances with other companies and $45.16 \%$ do not belong to any guild (Lastre Sierra, 2016). Although the absence of strategies aimed at promoting alliances among tour operators is probable, the fact is that the lack of knowledge of the existence of this kind of associations (52.94\%) deprives the effectiveness of the efforts made by the managers and guilds. Hence, the need to direct strategies, policies and management towards the promotion of alliances amongst tourism operators of the largest and most important industry in the area.

As a result, the Gulf of Morrosquillo being a privileged destination among local tourists, in recent years the demand for this destination has increased at a national level, especially the demand in the area of the municipality of Coveñas. About $74 \%$ of visitors come from different cities in the country. However, the signs of lagging in the diversification of tourism activities have led to these activities revolving mostly around accommodation establishments. Public management must reduce the fact that some family groups prepare their homes and properties to provide these services without the minimum conditions of quality or hygiene (Lastre Sierra, 2016).

For the destination in general, it would be profitable that public management would encourage the design and the creation of tourism products-services that obey the reality of the market and the tastes of the visitors. The very few products and tourist attractions that the gulf has are not enough to arouse the interest of the visitants to stay more time or to visit the region in any other time but the vacation season. For that reason, the investment of the tourism providers for their own improvement observes the dynamics of the law of supply and demand of the destination, because the beaches of the gulf are just visited in the peak season; Making a huge investment in an establishment is not a profitable option for the owners, which is the reason why many of the providers tend to internalize the strategies of their competitors despite the particular conditions of each business. 
The lack of implementation of organizational practices, the entrepreneurs lag in the adoption of significant changes to the management and the scarce investment for integral improvement of the establishments (Lastre Sierra, 2016) are some of the subjects that within the public agenda area must.

It is absolutely necessary to provide public management with mechanisms that allow the reorientation of programs and policies to be implemented in areas that have tourism as one of its strengths and also, to be more effective in raising the awareness of the importance of promoting a shared, structured and sustainable growth in the Gulf of Morrosquillo that integrates the actions of the different interest groups such as: government, free enterprise, educational institutions, guilds, etc..

\section{Conclusions}

Although the present paper focused on critical analysis and the purpose of the role of the government and its management in consolidating the Gulf of Morrosquillo as a competitive tourism destination, it has deepened in the new trends of public management. Hence, the review of the literature on the subject allowed us to establish how the inclusion of the concepts, techniques and tools of professional management in the activities of the public sector has reconverted the management process. We now speak of new public management, conceived as an administration based on standards of efficiency and effectiveness, in order to meet the real needs of the population at the lowest possible cost.

The Gulf of Morrosquillo requires administrators committed to the common interest, capable of planning and envisioning the development of the region hand in hand with tourism; it also involves managers who have the necessary skills and abilities for the efficient management of resources and who are aware of the cooperative and integrated work. Government policies and instruments should focus on improving the conditions of the population, which should also aim at improving the tourism destination. However, the formulation of plans and programs should contemplate the study of the context to implement them, with the purpose of confronting the real problem directly.

The challenges of public management in the region go beyond what has been pointed out and studied in this paper. The poor management of the resources assigned not only to boost tourism activities but also to other equally important activities should be considered as well. It is not enough to be aware of the richness and natural beauty that the destination has or to boast about it. It is necessary for the local governments to be committed to enhance the conditions of the destination. It is useless to talk about all the vantages pointed out throughout this work, if they are not taken as to become competitive advantages.

This work was only an approach to some of the problems and challenges that the municipalities of the Gulf of Morrosquillo must face to consolidate the region as a competitive tourism destination, and it is also understandable that the public management process was not studied in depth. Therefore, it is advisable to carry out studies related to the topic and the problematic exposed here, bearing in mind, that the existing and ongoing studies do not fully cover the role of the state or of the local governments in the competitive development of tourism activities.

\section{References}

Aguilar, L. F. (2007). El aporte de la política pública y de la Nueva Gestión Pública a la gobernanza. Revista del CLAD Reforma y Democracia, 39, 1-15.

Arellano, D. (2002). Nueva gestión pública: ¿el meteorito que mató al dinosaurio? Lecciones para la reforma administrativa en países como México. Revista del CLAD Reforma y Democracia, 23, 9-40. 
Ávalos Aguilar, R. (1995). Innovación de la gestión pública: análisis y perspectiva. Gestión y estrategia, 6-17.

Cámara de Comercio de Sincelejo (Commerce Chamber of Sincelejo). (2015). Base de datos establecimientos de alojamiento 2015. Sincelejo, Sucre, Colombia.

Hood, C. (1991). A public management for all seasons? Public Administration, 69(1), 3-19.

Hood, C. (2000). The art of the state: Culture, rhetoric, and public management. Oxford University Press.

Lapsley, I., \& Oldfield, R. (2001). Transforming the public sector: Management consultants as agents of change. European Accounting Review, 10(3), 523-543.

Lastre Sierra, H. E. (2016). Análisis estratégico y competitivo de la industria de alojamiento turístico. Caso: Golfo de Morrosquillo, Departamento de Sucre. Sincelejo.

Lastre Sierra, H. E., \& Cruz Chávez, P. (2016a). Cluster turístico: de la competencia cooperativa al desarrollo estratégico. Retrieved from https://www.elsudcaliforniano.com.mx/columna/cluster-turistico-de-la-competencia-cooperativa-al-desarrollo-estrategico-del-destino

Lastre Sierra, H. E., \& Cruz Chávez, P. (2016b). La importancia de crear una política turística y evaluarla. Sudcaliforniano. Retrieved from http://www.oem.com.mx/elsudcaliforniano/notas/n4268068.htm

Losada, C. (1999). De burócratas a gerentes? Las ciencias de la gestión aplicadas a la administración del estado. IDB.

Lynn, L. E. (1996). Public management as art, science, and profession. Michigan: Chatham House Publishers.

Ministerio de Comercio, Industria y Turismo [MinCIT]. (2013). Registro Nacional de Turismo. Obtenido de Ministerio de Comercio, Industria y Turismo. Retrieved from http://www.mincit.gov.co/minturismo/publicaciones.php?id=12184

Ministerio de Comercio, Industria y Turismo [MinCIT]. (2016). Perfil económico: Departamento de Sucre. Bogotá: MINCIT.

Ochoa, H. H., \& Fuenmayor, J. (2006). Ni tecnocracia ni populismo: Hacia una gestión pública para la transformación en Venezuela. En El poder de los expertos: Para comprender la tecnocracia. Maracaibo: Universidad del Zulia.

Plan de Desarrollo 2012-2015: “Unidos es el camino”. Coveñas.

Plan de Desarrollo Municipal 2012-2015: “La oportunidad para todos!”. Santiago de Tolú.

Plan Departamental de Desarrollo de Sucre 2012-2015 “acciones claras para dejar huella”. Sincelejo: Gaceta Departamental de Sucre.

Red de Cámaras de Comercio (Network of Commerce Chambers). (n.d.). Prestadores de Servicios Turísticos. Obtenido de Registro Nacional de Turismo. Retrieved from http://rntsincelejo.confecamaras.co/establecimientos 